DOI: 10.12731/2070-7568-2020-4-207-225

УДК 332.146.2

\title{
ЭКОНОМИЧЕСКАЯ БЕЗОПАСНОСТЬ В РОССИЙСКОЙ АРКТИКЕ: ОЦЕНКА, НАПРАВЛЕНИЯ И ВОЗМОЖНОСТИ РЕГУЛИРОВАНИЯ
}

\section{Победоносиева В.В., Победоносиева Г.М.}

Экономическая безопасность региона оценивается по определённым критериям (пороговым значениям) показателями-индикаторами. Наиболее характерными для такой оченки являются показатели валового регионального продукта на душу населения в рублях на человека, инвестичий в основной капитал в \% от валового регионального продукта, уровня общей безработищь в \% и соотношение среднедушевых доходов населения и прожиточного минимума в разах. Анализ таких показателей и динамики их изменения за 2017-2018 годы, сопоставление их значений с пороговыми критериями в девяти регионах, полностью или частично входящих в Арктическую зону Российской Федерачии, показали, что среди них, безусловно, самым экономически безопасным был Ямало-Ненецкий автономный округ, отрасли хозяйствования которого соответствуют конъюнктуре мировых рынков, убедительныли и стабильным аутсайдером являлась Республика Карелия. Главным направлением регулирования уровня экономической безопасности в ответ на внутреннюю угрозу для регионов АЗРФ должно стать уравновешенное с экономическим развитием, параллельное последнему повышение уровня жизни населения.

Цель - оченка уровня экономической безопасности в Арктической зоне Российской Федерации и определение направлений и возможностей его регулирования.

Методы проведения работы: в статье использовались общенаучные методы познания, методы табличного и графического представления информации. 
Результаты: оченён уровень экономической безопасности в регионах Арктической зоны Российской Федеращии в 2017-2018 годах, предложены направления и определены возможности его регулирования.

Область применения результатов: полученные результаты цุелесообразно применять органам государственной власти всех уровней, особенно регионального и местного самоуправления субъектов Арктической зоны Российской Федерации.

Ключевые слова: Арктическая зона Российской Федерации; экономическая безопасность; критериальные показатели; валовой региональный продукт; инвестиции; безработица; прожтточный минимум.

\section{ECONOMIC SECURITY IN THE ARCTIC OF RUSSIA: ASSESSMENT, DIRECTIONS AND POSSIBILITIES OF REGULATION}

\section{Pobedonostseva V.V., Pobedonostseva G.M.}

The economic security of the region is assessed according to certain criteria (threshold values) indicator indicators. The most typical indicators for such an assessment are the indicators of the gross regional product per capita in rubles per person, investment in fixed assets in \% of the gross regional product, the level of total unemployment in $\%$ and the ratio of the average per capita income of the population to the subsistence minimum in times. Analysis of such indicators and the dynamics of their change for 2017-2018, comparison of their values with the threshold criteria in nine regions, fully or partially included in the Arctic zone of the Russian Federation, showed that among them, of course, the most economically secure was the Yamal-Nenets Autonomous Okrug. , whose economic sectors correspond to the conjuncture of world markets, the Republic of Karelia was a convincing and stable outsider. The main direction of regulating the level of economic security in response to the internal threat to the regions of the Russian Arctic should be balanced with economic development, parallel to the latter, an increase in the standard of living of the population.

Purpose is to assess the level of economic security in the Arctic zone of the Russian Federation and determine the directions and possibilities of its regulation. 
Methodology in the article used general scientific methods of cognition, methods of tabular and graphical presentation of information.

Results: the level of economic security in the regions of the Arctic zone of the Russian Federation in 2017-2018 was assessed, directions were proposed and the possibilities for its regulation were identified.

Practical implications: the results obtained are advisable to apply to public authorities of all levels, especially regional and local self-government of the subjects of the Arctic zone of the Russian Federation.

Keywords: Arctic zone of the Russian Federation; economic security; criteria indicators; gross regional product; investments; unemployment; living wage.

\section{Введение}

Сегодня в приарктических и не только государствах мира обострился интерес к арктическим территориям, усилилось многоаспектное присутствие в них. Всёэто явилось серьёзным вызовом для национальной, в том числе экономической, безопасности России. Для их обеспечения насущными и жизненно необходимыми стали активная экспансия Российской Федерации (РФ) в Арктическую зону РФ (АЗРФ) и плотное присутствие второй в последней. В связи с этим активизировалась законотворческая деятельность в сфере государственной арктической политики РФ и безопасного развития АЗРФ. Это подтверждают правовые документы последних лет: Государственная программа РФ «Социально-экономическое развитие АЗРФ» (Постановление Правительства РФ от 21.04.2014 № 366 в ред. от 05.06.2019); Указ Президента РФ от 05.03.2020 № 164 «Об Основах государственной политики Российской Федерации в Арктике на период до 2035 года»; Указ Президента РФ от 26.10.2020 № 645 «Стратегия развития АЗРФ и обеспечения национальной безопасности до 2035 года».

«Стратегия экономической безопасности Российской Федерации на период до 2030 года» [14] определяет экономическую безопасность как состояние защищённости национальной экономики от внешних и внутренних угроз, при котором обеспечиваются экономический суверенитет страны, единство ее экономического про- 
странства, условия для реализации стратегических национальных приоритетов Российской Федерации.

Исследованиями в области экономической безопасности занимались многие отечественные и зарубежные учёные, такие как Абалкин Л.И.[1], Балабанов В.С., Бухвальд Е.М., Глазьев С.Ю. [2], Тамбовцев В.Л., Татаркин А.И., Селин В.С. [16], Сенчагов В.К.[12], Винсент Кейбл [19], В. Хагер, Б. Бузан [17, 18], Ю. Ченг [20], Р.С. Каплан [21] и другие. Так, российскими экономистами (Глазьев С.Ю., Сенчагов В.К., Гончаренко Л.П.) разработан ряд методов оценки уровня экономической безопасности государства и регионов. В рамках НИР Института экономических проблем им. Г.П. Лузина КНЦ РАН (г. Апатиты Мурманской области) была разработана и впоследствии доработана в процессе практического применения система показателей экономической безопасности и их пороговые значения для арктического региона - Мурманской области, и проведена оценка уровня экономической безопасности [16].

Среди иностранных авторов основные элементы теории экономической безопасности исследовались У. Шарпом, В. Хагером, Г.И. Моргентау. Об управлении безопасностью писали М. Вэбер, С. Крофт, Д. Хауорт [23].

Финские исследователи Юха Капила и Харри Миккола (Финский институт международных отношений) в своей статье «Арктическое напряжение» высказывают своё мнение об интересах и управлении в сфере арктической экономической безопасности различных арктических и географически далёких от Арктики государств (России, Китая, США, Европейского Союза). На основе анализа этих аспектов учёные делают вывод о том, что вследствие глобализации Арктики и нового внимания к экономике центр внимания переместится с вопросов устойчивого развития Арктики на экономику, в которой предпочтение будет отдаваться добыче углеводородов (сложной с точки зрения нулевого воздействия на окружающую среду, но интересной), а также морскому транспорту, а управление Арктикой может обрести более сложный и комплексный характер, поскольку с появлением в регионе новых глобальных участников экономические и политические ставки серьезно увеличиваются [3]. 
Однако, как отмечает Н.В.Цейковец (СПбГУ), «идеи включения внутренних факторов в сферу национальной экономической безопасности так и не получили широкого распространения в среде западных исследователей, которые, как правило, сосредотачиваются лишь на внешних угрозах. Пусть со временем угрозы перестали быть только военными, но всё равно у большинства исследователей они остаются экзогенными» [15]. Как примеры исключения и отличия от конфронтационной западной стратегии экономической безопасности в пользу стратегии кооперативной тот же автор приводит взгляды британского экономиста Винсента Кейбла [19] и американского экономиста Джонатана Киршнера[22].

Цель работы состоит в оценке уровня экономической безопасности в Арктической зоне РФ и определении возможностей её регулирования и повышения.

\section{Материалы и методы исследования}

Материалами исследования послужили научные литературные источники, ресурсы сети Интернет. Использовались анализ, обобщение и систематизация, общенаучные методы познания, методы табличного и графического представления информации.

\section{Результаты исследования и их обсуждение}

В большинстве известных методик экономическая безопасность оценивается по определённым критериям показателями-индикаторами. Однако большое значение для оценки её уровня имеют не столько сами критериальные показатели, сколько их пороговые значения, превышение или не достижение которых угрожает экономической безопасности региона.

Для оценки уровня экономической безопасности регионов АЗРФ нами были выбраны четыре индикатора из методики авторитетного специалиста в сфере экономической безопасности академика В.К. Сенчагова [12]: два так называемых показателя экономического развития и два - социального. Это соответственно показатели валового регионального продукта на душу населения (ВРП на д.н., руб/ чел), инвестиций в основной капитал (инвестиции в ОК, \% ВРП) и 
уровень общей безработицы (в \%) и соотношение среднедушевых доходов населения и прожиточного минимума (далее - доход/мин, раз). При их выборе авторы руководствовались следующими соображениями. Жизнедеятельность в АЗРФ требует освоения и применения новых высоких технологий, следовательно, потребуется другой качественный уровень человеческого капитала, а, значит, новое, лучшее качество жизни населения российской Арктики. Поэтому необходимым представляется рассмотреть показатели социальной сферы. Кроме того, показатели социального развития включены в рассмотрение как «характеризующие приемлемые для населения условия жизни и устойчивость социально-экономической ситуации» [4], а экономическая безопасность - одно из главных условий устойчивости регионального развития. К тому же конечная цель повышения безопасности любого вида - безопасность населения страны и регионов. Выбранные же индикаторы экономического развития являются обобщающими работу всех сфер экономики регионов и важны в сравнении уровней развития экономики и качества жизни в АЗРФ.

Отметим, что существуют разные взгляды на то, какие показатели необходимо использовать для оценки уровня экономической безопасности в регионах $[4,7]$, не всегда полностью совпадающие с [14]. И, разумеется, в рамках одной статьи невозможно проанализировать абсолютно все такие показатели. Поэтому по итогам анализа значений выбранных показателей в регионах АЗРФ авторы делают весьма осторожные выводы. Пороговые значения взяты из [12].

Другая трудность заключается в том, что лишь 4 региона АЗРФ являются полностью в неё входящими субъектами РФ (Ямало-Ненецкий и Ненецкий автономные округа, хотя и не отдельные субъекты РФ, но также относительно самостоятельные административно-территориальные единицы). Остальные анализируемые регионы - это районы и/или городские округа неарктических субъектов РФ. Найти отдельные статистические данные по ним очень сложно, да и ввиду их неполной самостоятельности представляется не совсем корректным сравнивать их показатели с самостоятельными субъектами АЗРФ. Поэтому авторы взяли на себя смелость рассмотреть, наравне с Ямало-Ненецким, Ненецким, Чукотским автономными округами 
(соответственно ЯНАО, НАО, ЧАО) и Мурманской областью, те неарктические в целом субъекты РФ, в которые входят регионы АЗРФ, учитывая это обстоятельство при анализе.

В таблице 1 представлены значения показателей экономической безопасности девяти регионов, полностью или частично входящих в АЗРФ. В таблице регионы размещены в такой последовательности, в какой они с запада на восток расположены в России.

Каждый год регионы занимают определённые места друг относительно друга в зависимости от значений показателей. Динамика изменений позиций регионов в 2017-2018 гг. приведена в схемах на рисунках 1, 2.

Проанализируем таблицу и рисунки.

Сразу можно отметить, что в 2017-2018 гг. по всем четырём показателям и по тем их значениям, которые лучше пороговых, лидирующие позиции, главным образом, у территориальных субъектов, полностью входящих в АЗРФ. Большую часть первых позиций занимал ЯНАО, ни разу не спустившись ниже 2 места. По ВРП на д.н. в оба года его опережал НАО, однако ЯНАО в 2018 году показал наилучшую положительную динамику по этому показателю

Таблииа 1.

Показатели экономической безопасности и их пороговые значения

в регионах АЗРФ

\begin{tabular}{|c|c|c|c|c|c|c|c|c|c|}
\hline \multirow{4}{*}{$\begin{array}{l}\text { № } \\
\text { ח/ח }\end{array}$} & \multirow{3}{*}{ Регионы АЗРФ } & \multicolumn{8}{|c|}{ Показатели экономической безопасности региона ${ }^{1}$} \\
\hline & & \multicolumn{2}{|c|}{$\begin{array}{c}\text { ВРП на душу } \\
\text { населения, Р/чел. }\end{array}$} & \multicolumn{2}{|c|}{$\begin{array}{c}\text { Инвестиции в } \\
\text { основной капи- } \\
\text { тал, \% к ВРП }\end{array}$} & \multicolumn{2}{|c|}{$\begin{array}{l}\text { Уровень безра- } \\
\text { ботицы, \% }\end{array}$} & \multicolumn{2}{|c|}{$\begin{array}{c}\text { Отношение среднедушевых } \\
\text { доходов населения к прожи- } \\
\text { точному минимуму, раз }\end{array}$} \\
\hline & & $2017^{3}$ & $2018^{4}$ & $2017^{5}$ & $2018^{6}$ & $2017^{3}$ & $2018^{7}$ & $2017^{3}$ & $2018^{8}$ \\
\hline & $\begin{array}{l}\text { Пороговые } \\
\text { значения }{ }^{2}\end{array}$ & \multicolumn{2}{|c|}{$>413200 \mathrm{P}$} & \multicolumn{2}{|c|}{$>25 \%$} & \multicolumn{2}{|c|}{$\begin{array}{l}<4 \% \text { по методо- } \\
\text { логии МОТ }\end{array}$} & \multicolumn{2}{|c|}{$>3,5$ pa3 } \\
\hline 1 & Мурманская область & 589996,9 & 642705,6 & 25,4 & 29,9 & 7 & 6,8 & 3,19 & 2,84 \\
\hline 2 & Республика Карелия & 404487,6 & 451436,4 & 16 & 15 & 8,6 & 8,7 & 2,39 & 2,27 \\
\hline 3 & Республика Коми & 679162,6 & 796759,7 & 23,4 & 19 & 7,8 & 7,3 & 2,66 & 2,62 \\
\hline 4 & $\begin{array}{c}\text { Архангельская область } \\
\text { без Ненецкого АО }\end{array}$ & 418370,2 & 464910,5 & 23,3 & 19,5 & 6,4 & 6,3 & 3,01 & 2,71 \\
\hline 5 & Ненецкий АО & 6288467,9 & 6950415,5 & 39 & 29,8 & 8 & 8,1 & 3,54 & 3,87 \\
\hline 6 & Ямало-Ненецкий АО & 4581150,1 & 5710130,2 & 43 & 33 & 3,2 & 2,1 & 4,71 & 5,11 \\
\hline 7 & Красноярский край & 654513,9 & 792980,5 & 22 & 18,5 & 5,7 & 4,9 & 2,95 & 2,58 \\
\hline 8 & Республика Саха (Якутия) & 951220,2 & 1123113,8 & 42 & 37 & 7,1 & 6,9 & 2,93 & 2,56 \\
\hline 9 & Чукотский АО & 1386085,3 & 1578496,1 & 18,2 & 19,3 & 2,9 & 3,1 & 4,43 & 3,65 \\
\hline
\end{tabular}

${ }^{1}$ основные показатели выбраны по [12] и на основе [14] и [7].

${ }^{2}$ По [12]. 
${ }^{3}$ По статсборнику ФСГС «Регионы России. Социально-экономические показатели. 2018» [9].

${ }^{4}$ Приведено по данным [5]

5Рассчитано по данным статсборника [9].

${ }^{6}$ Рассчитано по данным [5] (ВРП 2018) и статсборника ФСГС [10]

(инвестиции в основной капитал 2018).

${ }^{7}$ По статсборнику [10].

${ }^{8}$ Рассчитано по данным статсборника ФСГС «Регионы России.

Социально-экономические показатели. 2019» [10].
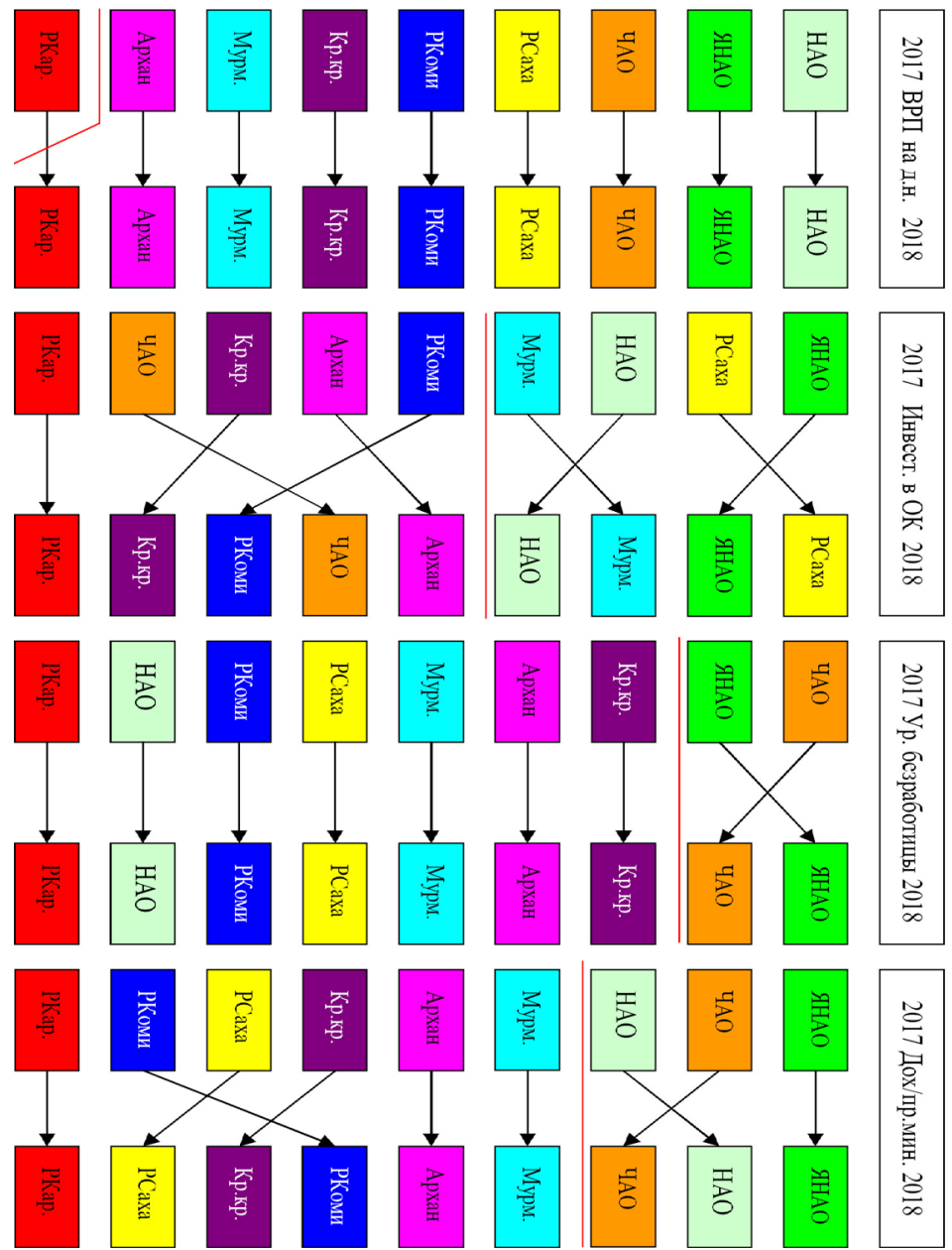

Рис. 1. Динамика относительного изменения позиций регионов АЗРФ по значениям показателей экономической безопасности 


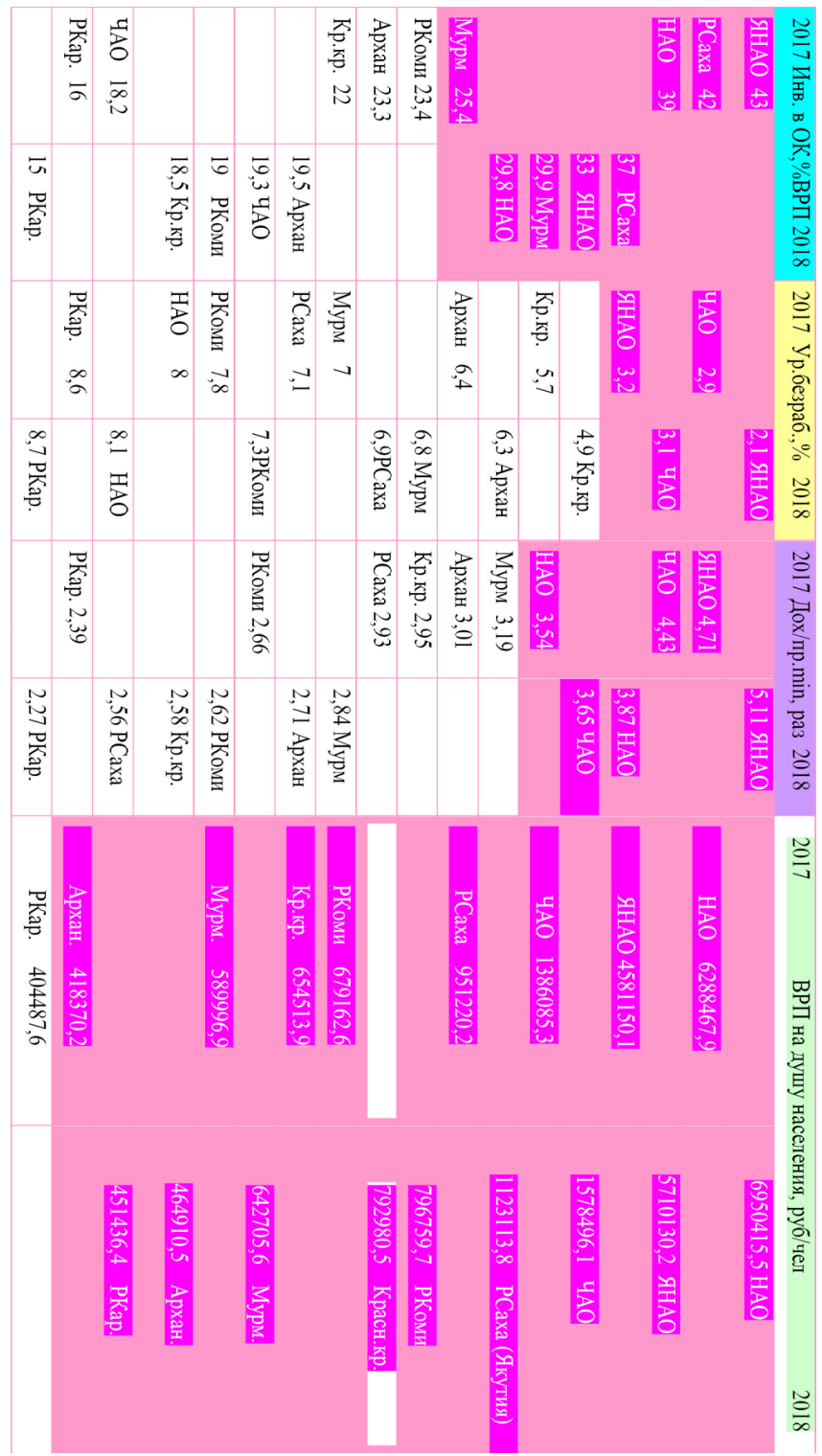

Рис. 2. Динамика абсолютного изменения позиций регионов АЗРФ относительно друг друга по значениям показателей экономической безопасности (розовым цветом выделены значения показателей лучше пороговых критериев) 
(+1128980,1 руб/чел) среди всех 9 рассматриваемых регионов. Очевидно следующее объяснение этих фактов.

В последние 15 лет благодаря конъюнктуре мировых рынков интенсивно по сравнению с другими отраслями развивался топливноэнергетический комплекс (ТЭК) России. Его топливодобывающая компонента в настоящее время смещена на Северо-Восток страны, главным образом, в Арктическую зону. ЯНАО - один из стратегических регионов-доноров России. Он в настоящее время является крупнейшим в России центром газодобывающей промышленности. Устойчивое социально-экономическое развитие Российской Федерации обеспечивается, во многом, функционированием нефтегазового сектора ЯНАО [13]. Регион сейчас бурно развивается, в нём работает крупный бизнес - такие компании как «Газпром», «НОВАТЭК», «Газпром нефть», и высокие показатели социального развития округа говорят о высокой же социальной ответственности этих компаний.

Здесь же следует уточнить, что в НАО, опережавшем ЯНАО по среднедушевому ВРП в 2017-2018 гг., численность населения на порядок ниже, чем в ЯНАО, кроме того, в эти годы в НАО наблюдался высокий уровень безработицы. Это ещё раз доказывает, что «высокие среднедушевые значения

ВРП не отражают объективной характеристики эффективности региональной экономики, не свидетельствуют о более высоком уровне социально-экономического развития территории» и «является лишь приблизительной мерой благосостояния населения» и реального уровня его доходов [11].

По среднедушевому ВРП в 2017 г. регионы можно условно распределить по 4 группам, состав которых и порядок размещения регионов в которых не изменились в 2018 г. Первую группу лидеров с большим отрывом составили НАО (1 место) и ЯНАО (2). Во вторую группу с ВРП на д.н. больше 1000000 руб/чел вошли ЧАО и Республика Саха (Якутия). Третья группа включает 3 региона с показателями больше 500000 руб/чел, но меньше 1000000 руб/ чел. Это Республика Коми (5), Красноярский край (6) и Мурманская область (7). Причём Красноярский край в 2018 году превысил 
значение Республики Коми 2017 года. И, наконец, четвёртая группа - группа аутсайдеров: Архангельская область (8) и Республика Карелия (9). Республика Карелия в 2017 году показала значение индикатора ниже порогового, но в 2018 году превысила пороговое значение и даже значение Архангельской области 2017 года. В Архангельской же области наблюдалась самая низкая среди всех регионов, хотя и положительная, динамика показателя (+46540,3 руб/ чел). Все рассматриваемые регионы, кроме Республики Карелии в 2017 г., достигли уровня среднедушевого ВРП в оба года выше (лучше) порогового значения и в 2018 г. увеличили свои ВРП на д.н. по сравнению с 2017 г.

Объёмы инвестиций в основной капитал (в \% ВРП) в 2017 году у 7 из 9 регионов были весьма высокими: или значительно выше порогового значения (ЯНАО, Республика Саха, НАО), или близко к нему (Мурманская область, Республика Коми, Архангельская область, Красноярский край). Отстающими стали ЧАО $(18,2 \%)$ и Республика Карелия. В 2018 году 7 из 9 территориальных субъектов АЗРФ резко снизили этот показатель. Его значения выросли только у Мурманской области (до 29,9\%) и у ЧАО (до 19,3\%), причём последний, тем не менее, порог не перешёл. Наилучшую динамику показала Мурманская область (+4,5\%), а наихудшую (-10\%) - ЯНАО. Отстала от всех снова Республика Карелия с показателями 16\% в 2017 г. и $15 \%$ - в 2018 г.

Самые низкие показатели уровня общей безработицы в 2017 2018 гг. у ЧАО и ЯНАО. Только у этих двух субъектов АЗРФ значения безработицы ниже пороговых 4 \%. В 2017 году ЧАО на первом месте (2,9\%), ЯНАО - на втором (3,2\%). Но уже в 2018 г. ЯНАО с самой большой среди 9 регионов положительной динамикой $(-1,1 \%)$ на первом месте $(2,1 \%)$, ЧАО с самой большой отрицательной динамикой $(+0,2 \%)$ - на втором $(3,1 \%)$. Относительно высокий уровень безработицы показали Мурманская область и НАО, в 2018 г. в Мурманской области безработица снизилась на 0,2 \% до 6,8\%, а в НАО, наоборот, выросла на 0,1\% до 8,1\%. Среди остальных регионов, превысивших порог, явный аутсайдер - Республика Карелия с 
8,6\% в 2017 году и с ростом на 0,1 \% до 8,7 \% в 2018 г. Красноярский край, Архангельская область, Республики Саха (Якутия) и Коми в 2018 г. снизили уровень безработицы, но не ниже 4\%.

Что касается показателя отношения среднедушевых доходов населения к прожиточному минимуму в арктических регионах, то все первые позиции и в 2017 г. и в 2018 г. заняли субъекты РФ, чьи территории полностью входят в АЗРФ. Вероятно, это связано с искажениями, обусловленными использованной методикой, учитывающей регионы, не входящие в АЗРФ целиком, как полностью относящиеся к АЗРФ. Безусловный лидер здесь - ЯНАО, ещё более повысивший значение показателя в 2018 г., тем подтвердивший своё первенство. В 2017 году второе место у ЧАО, третье - у НАО. Мурманская область, единственная из четырёх не перешедшая порог, на четвёртом месте. В 2018 году ЧАО ухудшил свой показатель, а НАО улучшил, в итоге НАО на втором, а ЧАО на третьем месте. Мурманская область (снова четвёртое место) снизила в 2018 г. величину показателя и опять осталась ниже порогового значения. Все остальные субъекты РФ, не полностью вошедшие в АЗРФ, в эти годы остались ниже пороговой планки, причём в 2018 г. ухудшили свои результаты. Убедительным аутсайдером и здесь стала Республика Карелия.

Такая ситуация по данному показателю, видимо, означает следующее. Основная экономическая специализация ЯНАО, НАО, Мурманской области и ЧАО - добыча полезных ископаемых. Эта область промышленности в России сейчас одна из самых высокооплачиваемых. Кроме того, надо учесть полярные надбавки к заработной плате в этих регионах. Небольшие значения показателя в остальных регионах, вероятно, говорят о невысоких зарплатах в них.

Итак, в 2017-2018 гг. по рассмотренным показателям самым экономически безопасным в АЗРФ является Ямало-Ненецкий АО. Меньше всего регионов АЗРФ с показаниями лучше пороговых по социальным показателям: уровню безработицы и отношению среднедушевых доходов населения к прожиточному минимуму. Это, скорее всего, говорит о том, что в большинстве регионов АЗРФ качество жизни населения отстаёт от уровня их экономического раз- 
вития, что было обосновано также в [8]. Значит, в этих регионах существуют угрозы экономической безопасности. В основном качество жизни арктического населения высокое там, где работают и проявляют социальную ответственность крупные добывающие топливные и другие ресурсы с высокой рыночной конъюнктурой компании, хотя оборотной стороной таких высоких показателей является низкая устойчивость этих регионов по отношению к шокам на рынках природных ресурсов.

Представляется уместным упомянуть здесь в связи с этим авторов [6], которые ещё в 2010 г. отмечали, что «в большинстве северных регионов РФ, несмотря на достаточно высокий сложившийся в них промышленный потенциал, уровень социального развития низкий», а «например, в 2008 г. более 1/3 населения Республики Карелия не смогли обеспечить себе социально приемлемый уровень жизни, сложившийся в регионе»[6, с. 163, 168].

\section{Заключение}

Таким образом, главным направлением регулирования уровня экономической безопасности в ответ на внутреннюю угрозу для регионов АЗРФ должно стать уравновешенное с экономическим развитием, параллельное последнему повышение уровня жизни населения. Такой процесс особенно важен для России, так как отныне крайне необходимо её постоянное плотное присутствие в своей Арктической зоне.

На наш взгляд, в целом существуют следующие возможности регулирования экономической безопасности и повышения её уровня в регионах:

- мониторинг опасностей и внешних и внутренних угроз экономике регионов;

- мониторинг сравнения значений показателей экономической безопасности с пороговыми значениями;

- воздействия на причины и источники опасностей и угроз в целях их устранения или нейтрализации и тем самым обеспечения экономической безопасности в регионах; 
- воздействия на экономику региона в целях достижения и/или не ухудшения пороговых значений показателей экономической безопасности в регионе;

- деятельность, имеющая положительный эффект для экономического развития регионов, и её поддержка;

- учёт взаимодействия в экономическом развитии регионов глобальных, национальных и региональных факторов.

Информация о конфликте интересов. Авторы заявляют об отсутствии конфликта интересов.

Информация о спонсорстве. Исследование не имело спонсорской поддержки.

\section{Список литературы}

1. Абалкин Л.И. Экономическая безопасность России: угрозы и их отражение // Вопросы экономики. № 12, 1994. С. 4-14.

2. Глазьев С.Ю. Основа обеспечения экономической безопасности страны: альтернативный реформационный курс // Российский журнал. 1997. № 1.

3. Капила Ю., Миккола Х. Арктическое напряжение. Maritime News of Russia. 18.11.2014. [Электронный ресурс] URL:http://www.morvesti. $\mathrm{ru} /$ themes/1698/53313/ (дата обращения 26.11.2020)

4. Кузнецова Е. И. Экономическая безопасность : учебник и практикум для вузов. М.: Издательство Юрайт, 2019. 294 с.

5. Мордовиястат. Территориальный орган ФСГС по Республике Мордовия. Валовой региональный продукт 1998-2018 [Электронный ресурс]. URL: https://mrd.gks.ru/folder/27963 (дата обращения 30.03.2020).

6. Особенности и сценарии социально-экономического развития современного Севера России. М.: Экономика, 2010. 238 с.

7. Павленко В.И. Арктическая зона Российской Федерации в системе обеспечения национальных интересов страны // Арктика: экология и экономика. № 4 (12). 2013. С.16-25.

8. Победоносцева В.В., Победоносцева Г.М. О базовых принципах и приоритетах развития российской Арктики с учётом фактора глобализации // Наука Красноярья, 2019. Т. 8, № 5-3, 182 с. С.116-123. 
9. Регионы России. Социально-экономические показатели. 2018: Стат. сб. / Росстат. М., 2018. 1162 с.

10. Регионы России. Социально-экономические показатели. 2019: Стат. сб. / Росстат. М., 2019. 1204 с.

11. Савалей В.В. Валовой региональный продукт как индикатор эффективности и уровня развития территориальной экономики // Территория новых возможностей. Вестник Владивостокского государственного университета экономики и сервиса. 2017. Т. 9, № 2. С. 31-43.

12. Сенчагов В. К., Митяков С. И. Индикаторы устойчивого развития регионов Российской Федерации // Проблемы устойчивости функционирования стран и регионов в условиях кризисов и катастроф современной цивилизации: тезисы докладов XVII международной научно-практической конференции. ФГБУ ВНИИ ГОЧС (ФЦ) МЧС России. М., 2012. С. 17-19.

13. Социально-экономическое положение в Ямало-Ненецком округе 2017-2018. Официальный сайт Главного федерального инспектора по Ямало-Ненецкому АО [Электронный ресурс]. URL: http://gfi89. uralfo.ru/soch-ekon/ (дата обращения 29.03.2020 г.).

14. Указ Президента РФ от 13.05.2017 № 208 «О Стратегии экономической безопасности Российской Федерации на период до 2030 года» [Электронный ресурс]. URL: https://www.garant.ru/products/ ipo/prime/doc/71572608/ (дата обращения 15.03.2020).

15. Цейковец Н.В. Концептуальные подходы к пониманию и обеспечению национальной экономической безопасности: научные теории и государственные стратегии // Журнал НЭА (Новойэкономической ассоциации), №1 (29), 2016, С. 129-157.

16. Экономическая безопасность российской Арктики: особенности и проблемы обеспечения / под науч. ред. В.С. Селина, Т.П. Скуфьиной, Е.П. Башмаковой, М.В. Ульченко. Апатиты: изд. КНЦ РАН, 2018. 103 с.

17. Buzan B. New Patterns of Global Security in the Twenty-First Century" [Электронный ресурс] // International Affairs. 1991. Vol. 67, No. 3. URL: http://euroakadeemia.ee/materjalid/Buzan\%20-\%20New\% 20Patterns $\% 20$ of $\% 20$ Global $\% 20$ Security $\% 20 \mathrm{in} \% 20$ the $\% 2021$ st $\% 20$ Century. pdf (дата обращения 12.03.2020). 
18. Buzan B. People, states and fear. Brighton, 1983, p. 13-14.

19. Cable V. What is International Economic Security? // International Affairs (Royal Institute of International Affairs 1944). 1995. V.71. № 2. P. 305-324.

20. Cheng, Y. Income inequality and applications to China / Y. Cheng, S. Li // Economics Letters. 2006. No. (91). Pp. 8-14.

21. Kaplan, R. S. Strategy Maps: Converting Intangible Assets into Tangible Outcomes / R. S. Kaplan, D. P. Norton. Boston, Massachusetts, USA: Harvard Business School Press, 2004. 324 p.

22. Kirshner J. PoliticalEconomy in Security Studies after the Cold War //Review of International Political Economy. 1998. Vol.5. No.1. P. 64-91.

23. Webber M., Croft S., Howorth J. The governance of European security // Review of International Studies. Volume 30, Issue 1, January 2004, pp. 3-26.

\section{References}

1. Abalkin L.I. Ekonomicheskaya bezopasnost' Rossii: ugrozy i ikh otrazheniye [Economic security of Russia: threats and their reflection]. Voprosy ekonomiki [Problems of Economics]. no. 12, 1994, p. 4-14.

2. Glaz'yev S.YU. Osnova obespecheniya ekonomicheskoy bezopasnosti strany: al'ternativnyy reformatsionnyy kurs [The basis for ensuring the country's economic security: an alternative reform course]. Rossiyskiy zhurnal [Russian journal]. 1997. No. 1.

3. Kapila Y.U., Mikkola K.H. Arkticheskoye napryazheniye [Arctic stress] Maritime News of Russia. 11/18/2014. http://www.morvesti.ru/ themes/1698/53313/

4. Kuznetsova, Ye.I. Ekonomicheskaya bezopasnost': uchebnik i praktikum dlya vuzov [Economic security: textbook and workshop for universities]. Moscow. Yurayt Publishing House, 2019 . 294 p.

5. Valovoy regional'nyy produkt 1998-2018. [Gross Regional Product 1998-2018] Mordoviyastat. Territorial'nyy organ FSGS po Respublike Mordoviya. [Mordoviastat. FSSS territorial body in the Republic of Mordovia]. https://mrd.gks.ru/folder/27963

6. Osobennosti $i$ stsenarii sotsial'no-ekonomicheskogo razvitiya sovremennogo Severa Rossii [Features and scenarios of socio-economic 
development of the modern North of Russia]. Moscow. Economics, 2010. 238 p.

7. Pavlenko V.I. Arkticheskaya zona Rossiyskoy Federatsii v sisteme obespecheniya natsional'nykh interesov strany [Arctic zone of the Russian Federation in the system of ensuring the national interests of the country]. Arktika: ekologiya i ekonomika. [Arctic: ecology and economics]. no. 4 (12). 2013. p.16-25.

8. Pobedonostseva V.V., Pobedonostseva G.M. O bazovykh printsipakh i prioritetakh razvitiya rossiyskoy Arktiki s uchotom faktora globalizatsii [On the basic principles and priorities of the development of the Russian Arctic, taking into account the factor of globalization]. Nauka Krasnoyar'ya [Siberian Journal of Economics and Management], vol. 8. no. 5-3, 2019. 182 p. Pp. 116-123.

9. Regiony Rossii. Sotsial'no-ekonomicheskiye pokazateli. 2018 [Regions of Russia. Socio-economic indicators 2018]. Stat. sb. Rosstat. Moscow. 2018. $1162 \mathrm{p}$.

10. Regiony Rossii. Sotsial'no-ekonomicheskiye pokazateli. 2019 [Regions of Russia. Socio-economic indicators. 2019]. Stat. sb. Rosstat. Moscow. 2019. 1204 p.

11. Savaley V.V. Valovoy regional'nyy produkt kak indikator effektivnosti i urovnya razvitiya territorial'noy ekonomiki [Gross regional product as an indicator of efficiency and the level of development of the territorial economy]. Territoriya novykh vozmozhnostey. Vestnik Vladivostokskogo gosudarstvennogo universiteta ekonomiki i servisa [Territory of new opportunities. Bulletin of the Vladivostok State University of Economics and Service]. 2017. vol. 9, no. 2. p. 31-43.

12. Senchagov V. K., Mityakov S. I. Indikatory ustoychivogo razvitiya regionov Rossiyskoy Federatsii [Indicators of sustainable development of regions of the Russian Federation]. Problemy ustoychivosti funktsionirovaniya stran i regionov $v$ usloviyakh krizisov $i$ katastrof sovremennoy tsivilizatsii: tezisy dokladov XVII mezhdunarodnoy nauchno-prakticheskoy konferentsii [Problems of sustainable functioning of countries and regions in the conditions of crises and catastrophes of modern civilization: abstracts of the XVII international scientific-prac- 
tical conference]. FGBU VNII GOCHS (FTS) MCHS Rossii. Moscow, 2012, pp. 17-19.

13. Sotsial'no-ekonomicheskoye polozheniye v Yamalo-Nenetskom okruge 2017-2018. [Socio-economic situation in the region 2017-2018]. Ofitsial'nyy sayt Glavnogo federal'nogo inspektora po Yamalo-Nenetskomu $A O$ [Official site of the Chief Federal Inspector for the Yamalo-Nenets Autonomous District]. http://gfi89.uralfo.ru/soch-ekon/

14. Ukaz Prezidenta RF ot 13.05.2017 № 208 «O Strategii ekonomicheskoy bezopasnosti Rossiyskoy Federatsii na period do 2030 goda» [Decree of the President of the Russian Federation of May 13, 2017 No. 208 "On the Strategy of Economic Security of the Russian Federation for the Period until 2030"]. https:/www.garant.ru/products/ipo/prime/doc/71572608/

15 . Tseykovets N.V. Kontseptual'nyye podkhody k ponimaniyu i obespecheniyu natsional'noy ekonomicheskoy bezopasnosti: nauchnyye teorii i gosudarstvennyye strategii [Conceptual approaches to understanding and ensuring national economic security: scientific theories and state strategies]. Zhurnal NEA (Novoy ekonomicheskoy assotsiatsii [Journal of the NEA (New Economic Association)], No. 1 (29), 2016, p. 129-157.

16. Ekonomicheskaya bezopasnost' rossiyskoy Arktiki: osobennosti i problemy obespecheniya [Economic security of the Russian Arctic: features and problems of support]/ under scientific. ed. V.S. Selina, T.P. Skufina, E.P. Bashmakova, M.V. Ulchenko. Apatity: KSC RAS, 2018 . 103 p.

17. Buzan, B. New Patterns of Global Security in the Twenty-First Century. International Affairs. 1991. Vol. 67, No. 3.

18. Buzan B. People, states and fear. Brighton, 1983, p. 13-14.

19. Cable V. What is International Economic Security? International Affairs (Royal Institute of International Affairs 1944). 1995. V.71. № 2. P. 305-324.

20. Cheng Y., Li S. Income inequality and applications to China. Economics Letters. 2006. No. (91). Pp. 8-14.

21. Kaplan, R.S. Strategy Maps: Converting Intangible Assets into Tangible Outcomes. R.S. Kaplan, D.P. Norton. Boston, Massachusetts, USA: Harvard Business School Press, 2004. 324 p.

22. Kirshner J. PoliticalEconomy in Security Studies after the Cold War. Review of International Political Economy. 1998. Vol.5. No.1. P. 64-91. 
23. Webber M., Croft S., Howorth J. The governance of European security. Review of International Studies. Volume 30, Issue 1, January 2004, pp. 3-26.

\section{ДАННЫЕ ОБ АВТОРАХ}

Победоносцева Вероника Валерьевна, старший научный сотрудник, кандидат экономических наук Центр физико-технических проблем энергетики Севера Федерального исследовательского ичентра «Кольский научный иентр» Российской академии наук ул. Ферсмана, 21A, г. Апатиты, 184209, Российская Федераџия v.pobedonosceva@ksc.ru

Победоносцева Галина Михайловна, научный сотрудник Институт экономических проблем имени Г.П.Лузина Федерального исследовательского ичентра «Кольский научный иентр» Российской академии наук ул. Ферсмана, 21A, г. Апатиты, 184209, Российская Федерация pobedon@iep.kolasc.net.ru

\section{DATA ABOUT THE AUTHORS}

Pobedonosceva Veronika Valer'evna, Senior Researcher, Ph.D.(Econ.) Centre for Physical and Technic Problems of Energetics in Nothern Areas Federal Research Centre "Kola Science Centre" of RAS 21A, Fersman Str., Apatity, 184209, Russian Federation v.pobedonosceva@ksc.ru

ORCID: 0000-0002-9552-5891

SPIN-code: 6618-0477

\section{Pobedonosceva Galina Mihailovna, Researcher}

Luzin Institute for Economic Studies Federal Research Centre"Kola Science Centre" of RAS 21A, Fersman Str., Apatity, 184209, Russian Federation pobedon@iep.kolasc.net.ru 